\title{
Analysis of Scopus-Indexed Scientific Publication of Lecturers in Maluku at SINTA Portal
}

\author{
Jusuf Nikolas Anamofa ${ }^{1}$, Ricardo Freedom Nanuru ${ }^{2}$ \\ \{anamofaj@gmail.com ${ }^{1}$,ricardonanuru632@gmail.com ${ }^{2}$ \} \\ ${ }^{1}$ Indonesian Language and Literature Education Study Program, STKIP Gotong Royong, Masohi \\ ${ }^{2}$ Theology Faculty, Halmahera University, Tobelo
}

\begin{abstract}
Research conducted by a lecturer should be published as a scientific communication in the scientific community. Ministry of Research, Technology, and Higher Education of Republic Indonesia has built a system that provides comprehensive and accessible information about Indonesian scientific publications called SINTA. Analysis of the Higher Education Database and SINTA portal shows that $17 \%$ of lecturers in Maluku have been registered as verified authors within the SINTA portal. The percentage of verified authors of Maluku lecturers compared with the total verified authors in the SINTA portal is $0.49 \%$. The percentage of Scopus-indexed publications from lecturers in Maluku compared with the total Scopus-indexed publication in the SINTA portal is $0.32 \%$. Most Scopus-indexed scientific publications are from Pattimura University which is $94 \%$. The publications tend to increase each year but decline in 2017 . Journal articles are the most publicized type of Scopus-indexed which is $90 \%$. The most widely published subject area is Natural sciences which is $98 \%$ of the total Scopusindexed publications.
\end{abstract}

Keywords: Scopus-Indexed, Scientific Publication, SINTA Portal, Lecturers in Maluku

\section{Introduction}

Scientific publication is an important part of the research process. By publishing, the findings of the research can be known by peer researchers in their field specifically and society in general. Researchers can also contribute theoretically and practically in the field of human life, not merely to pursue a career as a scientist [1], [2] because publication is the center of activity of the scientific community that affects the progress of science, either related to the results, methods, standards, or scientific principles [3]. There are three roles of scientific publication in the process of scientific communication, namely the social role to build and maintain intellectual property so that the work of researchers get recognition from the world of related disciplines, the archive role as an attempt to document the scientific work that has been evaluated and accepted by the world of science, and the dissemination role as an effort to disseminate scientific ideas in the perspective of scientific accumulation [4]. In addition, if the researcher is a teacher or a lecturer then scientific publication becomes the main requirement for the promotion of the functional position (Kemendikbud, 2016; Lukman, Ahmadi, Manalu, \& Hidayat, 2017).

One of the main duties of lecturers is to carry out research [7]. Publication should be the estuary of any research conducted. In fact, not all lecturers have published their research results even though the condition of Indonesian scientific publication has improved [8]. To 
encourage the number and quality of publications of research results, the government through Ministry of Research, Technology, and Higher Education of Republic Indonesia (Kemenristekdikti) build SINTA portal as a central index of publication of Indonesian researchers [9]. At first glance through the SINTA portal it is found that most of the university lecturers in Maluku under the Kemenristekdikti have not been registered. In addition, the number of Scopus-indexed publications of lecturers in Maluku is still very small. It means that the lecturers in Maluku have a very small contribution to the increase of Indonesia scientific publications. Scopus-indexed scientific publication is selected as the scope study because the data is available inside the SINTA portal.

The purpose of this study is to determine the ratio of the number of universities in Maluku in the Higher Education Database (PDPT) [10] to the number of universities enrolled in the SINTA portal [9]; comparison of the number of university lecturers in Maluku with the number of lecturers registered on SINTA; total number of Maluku lecturers' publications on SINTA, years of Scopus-indexed publication, type of Scopus-indexed publications, topics of Scopus-indexed publications, and the total number of lecturer's citation in Maluku on SINTA.

\section{Method}

This research used a descriptive method. The data were taken from PDPT (https://forlap.ristekdikti.go.id/) and SINTA Portal (http://SINTA2.ristekdikti.go.id/) in December 2017. For the SINTA portal, because of the continuous changes that occur every hour, particularly related to the total verified authors that impact on SINTA Score and SINTA Rank, the data collection time limitation was dated December 14, 2017 at 07.00 AM. Searching results are selected based on institutional affiliation, the number of authors verified, number of publications, year of Scopus-indexed publications, type of Scopus-indexed publication, topics of Scopus-indexed publications, and number of citations.

\section{Finding And Discussion}

There are 30 universities in Maluku affiliated to Kemenristekdikti, consisting of 3 State Universities (10\%) and 27 Private Universities (90\%). Out of 30 universities, 29 universities (97\%) have been registered on SINTA and 1 university (3\%), which is STKIP Hunimua has not been registered yet.

Table 1. Comparison of The Number of Lecturers in Maluku with The Number of Verified Authors in The SINTA Portal.

\begin{tabular}{clrrr}
\hline No. & \multicolumn{1}{c}{ Affiliation } & Lect. & Aut. & \% \\
\hline 1 & Pattimura University & 1.083 & 264 & $24 \%$ \\
2 & Darussalam University Ambon & 122 & 12 & $10 \%$ \\
3 & Iqra University Buru & 69 & \multicolumn{1}{l}{7} & $10 \%$ \\
4 & Ambon State Polytechnic & 246 & 37 & $15 \%$ \\
5 & Tual State Fishery Polytechnic & 87 & 15 & $17 \%$ \\
6 & Indonesian Christian University of Maluku & 127 & 10 & $8 \%$ \\
7 & Maluku Maritime Academy & 24 & 1 & $4 \%$ \\
8 & STIA Trinitas & 17 & 1 & $6 \%$ \\
\hline
\end{tabular}




\begin{tabular}{clrrr}
\hline No. & \multicolumn{1}{c}{ Affiliation } & Lect. & Aut. & \% \\
\hline 9 & STP Hatta-Sjahrir Banda & 17 & 0 & 0 \\
10 & STIA Darul Rahman Tual & 12 & 0 & 0 \\
11 & STIA Abdul Azos Kataloka & 23 & 0 & 0 \\
12 & STIE Umel & 14 & 0 & 0 \\
13 & STIS Mutiara & 14 & 0 & 0 \\
14 & STIA Langgur & 8 & 0 & 0 \\
15 & STISIP Kebangsaan & 23 & 0 & 0 \\
16 & STIE Saumlaki & 15 & 0 & 0 \\
17 & STKIP Gotong Royong & 24 & 1 & $4 \%$ \\
18 & STIEM Rutu Nusa & 12 & 0 & 0 \\
19 & STIA Said Perintah & 12 & 0 & 0 \\
20 & STIA Saumlaki & 9 & 0 & 0 \\
21 & STKIP Hatta Sjahrir & 10 & 1 & $10 \%$ \\
22 & STIKES Maluku Husada & 23 & 0 & 0 \\
23 & STIKES Pasapua Ambon & 12 & 0 & 0 \\
24 & STIKOM Ambon & 21 & 1 & $5 \%$ \\
25 & STKIP Saumlaki & 11 & 0 & 0 \\
26 & STIH Muhammad Thaha Tual & 8 & 0 & 0 \\
27 & STKIP Ita Wotu Nusa & 11 & 0 & 0 \\
28 & Aru Midwifery Academy & 5 & 0 & 0 \\
29 & Akper Rumkit Tk. III Latumentten & 10 & 2 & $20 \%$ \\
Total & 2069 & $\mathbf{3 5 2}$ & $\mathbf{1 7 \%}$ & \\
\hline
\end{tabular}

(Notes: Lect. $=$ Lecturer, Aut. $=$ SINTA Verified Authors $)$

Table 1 shows the total number of lecturers at universities in Maluku registered in PDPT, which is 2,069 people while the number of lecturers registered in the SINTA portal as verified authors is 352 people (17\%) with the largest percentage coming from Pattimura University (75\%). The percentage of verified authors in Maluku is $0.49 \%$ of the total verified authors on the SINTA portal, which is 72,505 .

Table 2. Total Number of Lecturers in Maluku Scientific Publications and Citations on SINTA Portal.

\begin{tabular}{clrrrr}
\hline No. & \multicolumn{1}{c}{ Affiliation } & Scp & Scp Cit & GS & GS Cit \\
\hline 1 & Pattimura University & 174 & 4.565 & 1.805 & 9.374 \\
2 & Darussalam University Ambon & 5 & 5 & 110 & 140 \\
3 & Iqra University Buru & 2 & 8 & 91 & 95 \\
4 & Ambon State Polytechnic & 1 & 0 & 120 & 50 \\
5 & Tual State Fishery Polytechnic & 1 & 0 & 49 & 34 \\
6 & Indonesian Christian University of Maluku & 0 & 0 & 28 & 19 \\
7 & Maluku Maritime Academy & 2 & 2 & 10 & 5 \\
8 & STIA Trinitas & 0 & 0 & 10 & 2 \\
9 & STP Hatta-Sjahrir Banda & 0 & 0 & 0 & 0 \\
10 & STIA Darul Rahman Tual & 0 & 0 & 0 & 0 \\
11 & STIA Abdul Azos Kataloka & 0 & 0 & 0 & 0 \\
12 & STIE Umel & 0 & 0 & 0 & 0 \\
13 & STIS Mutiara & 0 & 0 & 0 & 0 \\
14 & STIA Langgur & 0 & 0 & 0 & 0 \\
15 & STISIP Kebangsaan & 0 & 0 & 0 & 0 \\
16 & STIE Saumlaki & 0 & 0 & 0 & 0 \\
17 & STKIP Gotong Royong & 0 & 0 & 6 & 0 \\
18 & STIEM Rutu Nusa & 0 & 0 & 0 & 0 \\
19 & STIA Said Perintah & 0 & 0 & 0 & 0 \\
\hline
\end{tabular}




\begin{tabular}{|c|c|c|c|c|c|c|}
\hline No. & Affiliation & & Scp & Scp Cit & GS & GS Cit \\
\hline 20 & STIA Saumlaki & & 0 & 0 & 0 & 0 \\
\hline 21 & STKIP Hatta Sjahrir & & 0 & 0 & 6 & 2 \\
\hline 22 & STIKES Maluku Husada & & 0 & 0 & 0 & 0 \\
\hline 23 & STIKES Pasapua Ambon & & 0 & 0 & 0 & 0 \\
\hline 24 & STIKOM Ambon & & 0 & 0 & 8 & 0 \\
\hline 25 & STKIP Saumlaki & & 0 & 0 & 0 & 0 \\
\hline 26 & STIH Muhammad Thaha Tual & & 0 & 0 & 0 & 0 \\
\hline 27 & STKIP Ita Wotu Nusa & & 0 & 0 & 0 & 0 \\
\hline 28 & Aru Midwifery Academy & & 0 & 0 & 0 & 0 \\
\hline \multirow[t]{2}{*}{29} & Akper Rumkit Tk. III Latumentten & & 0 & 0 & 6 & 0 \\
\hline & & Total & 185 & 4.580 & 2.249 & 9.721 \\
\hline
\end{tabular}

(Notes: $\mathbf{S c p}=$ Publications Indexed by Scopus, Scp Cit $=$ Scopus Citation, GS $=$ Google Scholar, GS Cit $=$ Google Scholar Citation)

Table 2 shows the number of Scopus-indexed publications is 185 , generated in 6 Universities (21\%) with the largest percentage coming from Pattimura University (94\%). The percentage of Scopus-indexed publication of lecturers in Maluku is $0.32 \%$ out of the total Scopus-indexed publications on SINTA portal which is 59,580. The number of citations in Scopus-indexed publications is 4,580 with the largest percentage of citation coming from publications on Pattimura University lecturers (99.67\%).

The number of publications indexed by Google Scholar is 2,249, generated by 12 Universities (41\%) with the largest percentage coming from Pattimura University (80\%). Percentage of publications indexed by Google Scholar of lecturers in Maluku is $0.27 \%$, out of total publication indexed by Google Scholar on SINTA portal which is 831,464 documents. Number of citations in publications indexed by Google Scholar is 9,721 with the largest percentage of citation coming from the publication of Pattimura University lecturers $(96 \%)$.

Table 3. Types of Scopus-Indexed Publications on 6 Universities in Maluku.

\begin{tabular}{rlrrr}
\hline No. & \multicolumn{1}{c}{ Affiliation } & \multicolumn{3}{c}{ Types of Scopus-Indexed Publication } \\
& & Journal Articles & Book Chapters & Conference Papers \\
\hline 1 & Pattimura University & 157 & 5 & 12 \\
2 & Darussalam University Ambon & 4 & 0 & 1 \\
3 & Iqra University Buru & 2 & 0 & 0 \\
4 & Ambon State Polytechnic & 1 & 0 & 0 \\
5 & Tual State Fishery Polytechnic & 1 & 0 & 0 \\
6 & Maluku Maritime Academy & 2 & 0 & 0 \\
\hline
\end{tabular}

Table 3 shows that Scopus-indexed scientific journals are the primary choice of lecturers in Maluku to publish their research results. In accordance with Scopus data, scientific journals are the most indexed source of data compared to conferences and books [11]. 


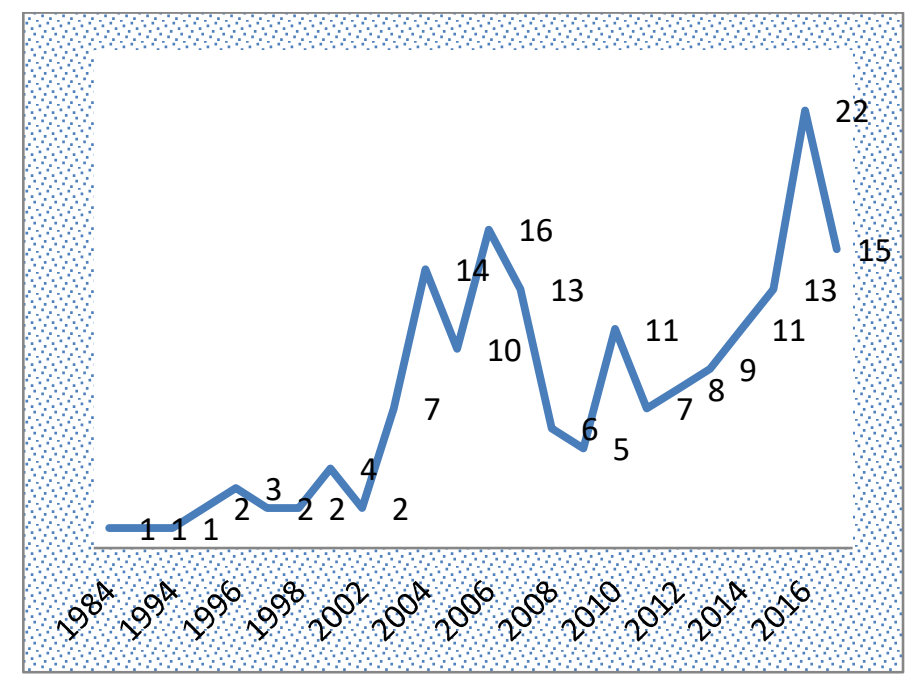

Fig. 1. Number of Scopus-indexed publications based on publication year.

Figure 1 shows that Scopus-indexed scientific publications tend to fluctuate since they were first indexed in 1984. Nevertheless, the trend of increase in publications per year occurred since 2011 to 2016 but declined in 2017.

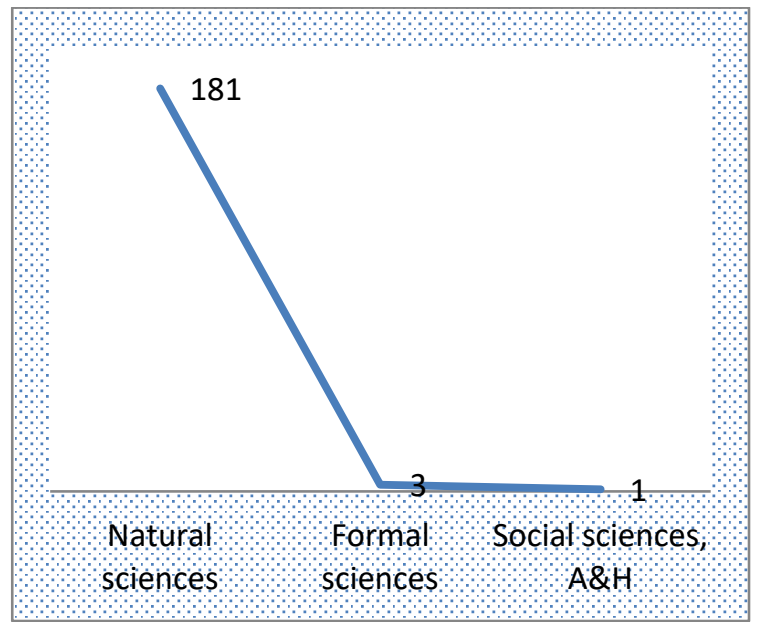

Fig. 2. Scopus Subject Coverage Area of Lecturers in Maluku Scientific Publication

Figure 3 shows that researchers in the field of natural sciences have published much of their research either in the form of Scopus-indexed journals articles, book chapters or conference papers compared to researchers in the fields of Social Sciences, Arts and Humanities) as well as Formal Science such as Mathematics. More specifically, Scopusindexed scientific fields include: (1) Life sciences involving Neuroscience, Pharmacology, and Biology; (2) Social sciences involving Psychology, Economics, Business, Arts and Humanities; (3) Physical sciences involving Chemistry, Physics, and Engineering; (4) Health sciences involving Medline, Nursing, Dentistry. If Life sciences, Physical sciences, and Health sciences are incorporated into Natural sciences, the Scopus-indexed publication title is more 
than Social Sciences, Arts and Humanities [11]. It is also in line with several findings regarding the difference in the number of publications by field of science in which Natural Sciences shows a high trend and increases year by year while Social Sciences, Arts and Humanities tend to be low and the increase is not significant [12]-[15].

\section{Conclusion}

Analysis of PDPT and SINTA portals can be used as data for mapping the scientific publications of lecturers in Maluku. It is expected that the lecturers who have not published the results of their research can do the publication as a professional responsibility. For lecturers who have conducted research publications but have not registered as verified author on SINTA portal should register themselves. Pattimura University as a State University included in the top 50 of SINTA rankings can help other universities in Maluku for scientific publications. Lecturers in the social sciences of humanities can be more active in publishing research results, possibly the Scopus-indexed one. In addition, all universities in Maluku have time to clean up to address these facts.

\section{References}

[1] W. McGuinness, “The future of scientific thought," J. R. Soc. New Zeal., vol. 45, no. 2, pp. 95$100,2015$.

[2] J. Offutt, "What Is the Purpose of Publishing?," 2011. .

[3] T. R. Cech, "Sharing Publication-Related Data and Materials: Responsibilities of Authorship in The Life Sciences." The National Academies Press, Washington, D.C., 2003.

[4] Tupan, "Analisis Karya Ilmiah Peneliti LIPI Pada Jurnal Internasional ScienceDirect," Visi Pustaka, vol. 17, no. 1, pp. 20-32, 2015.

[5] Kemendikbud, Buku 4: Pedoman Kegiatan Pengembangan Keprofesian Berkelanjutan Bagi Guru Pembelajar. Kementerian Pendidikan dan Kebudayaan Direktorat Jenderal Guru dan Tenaga Kependidikan, 2016.

[6] Lukman, S. S. Ahmadi, W. Manalu, and D. S. Hidayat, Pedoman Publikasi Ilmiah. Jakarta: Direktorat Pengelolaan Kekayaan Intelektual Direktorat Jenderal Penguatan Riset dan Pengembangan Kementerian Riset, Teknologi, dan Pendidikan Tinggi, 2017.

[7] Undang-undang Republik Indonesia Nomor 14 Tahun 2005 tentang Guru dan Dosen. Presiden Republik Indonesia, 2005.

[8] Ristekdikti, "Publikasi Internasional Indonesia Lampaui Thailand, Dirjen Ghufron Apresiasi Dosen dan Peneliti," 2017. .

[9] Ristekdikti, "SINTA - Science and Technology Index," 2017. .

[10] Kemenristekdikti, "SRV4 PDDIKTI : Pangkalan Data Pendidikan Tinggi," 2018.

[11] Elsevier, "Scopus Content Coverage Guide," no. August, 2017.

[12] V. Larivière, Y. Gingras, and É. Archambault, "Canadian collaboration networks: A comparative analysis of the natural sciences, social sciences and the humanities," in Scientometrics, 2006, vol. 68, no. 3, pp. 519-533.

[13] P. Dunleavy, "Poor citation practices are a form of academic self-harm in the humanities and social sciences," Writing for Research. 2014.

[14] Sindonews, "Bidang Kesehatan dan Teknik Masih Dominasi Publikasi," 2017. .

[15] W. Blockmans, "The underestimated humanities and social sciences," Qual. Assess. High. Educ., vol. c, pp. 89-94, 2007. 